\title{
MANAJEMEN WAKTU PENGANGKUTAN DALAM MEMINIMALISIR PENYUSUTAN BOBOT BADAN AYAM BROILER
}

\author{
Oleh : \\ ACHMAD MARZUKI *) , AHMAD ROBIUL AWAL UDIN**), dan JONI ARIFIN***)
}

\begin{abstract}
ABSTRAK
Proses transportasi ayam broiler dari kandang pemeliharaan ke rumah pemotongan ayam (RPA) bisa menimbulkan stres. Stres transportasi tidak dapat dihindari, namun bukan berarti bahwa dampak negatif stres tidak bisa dikurangi. Upaya alternatif menekan dampak merugikan stres transportasi salah satunya melalui manajemen waktu transportasi, yaitu transportasi pagi, siang, dan sore hari. Tujuan penelitian adalah untuk mengetahui waktu yang paling baik dan tepat untuk melakukan transportasi agar tidak terjadi penyusutan bobot badan yang terlalu tinggi. Penelitian dilaksanakan pada tanggal $8-9$ November 2011 di Politeknik Negeri Jember dan Desa Mangaran Situbondo dengan jarak tempuh $\pm 75 \mathrm{~km}$. Rancangan Percobaan yang digunakan dalam penelitian ini adalah Rancangan Acak Lengkap dengan 3 perlakuan dan 6 ulangan, setiap ulangan terdiri dari 5 ekor ayam broiler. Perlakuan 1 adalah transportasi ayam broiler pagi/dini hari (02.00 WIB) lama perjalanan 1 jam 32 menit, perlakuan 2 adalah transportasi ayam broiler siang hari (12.00 WIB) lama perjalanan 2 jam 11 menit, dan perlakuan 3 adalah transportasi ayam broiler sore hari (16.00 WIB) lama perjalan 1 jam 57 menit. Hasil penelitian diperoleh bahwa manajemen waktu pengangkutan berpengaruh sangat nyata $(\mathrm{P}<0.01)$ terhadap penyusutan bobot badan ayam broiler dan didapat hasil perlakuan terbaik yaitu perlakuan 1 (transportasi ayam broiler pagi/dini hari).
\end{abstract}

Kata kunci : Ayam Broiler, Transportasi, Stres, Penyusutan Bobot Badan.

\section{PENDAHULUAN}

\subsection{Latar Belakang}

Seiring dengan berkembangnya pengetahuan yang semakin modern, banyak masyarakat yang sadar akan kebutuhan nutrisi untuk memperbaiki kelangsungan hidupnya, terutama kebutuhan daging. Daging merupakan protein hewani yang memiliki kandungan gizi baik dan sangat dibutuhkan oleh tubuh, terutama bagi tubuh dalam masa pertumbuhan. Daging yang biasa dikonsumsi oleh masyarakat Indonesia, antara lain adalah daging sapi, kerbau, kambing, domba, ayam, dan daging babi (bagi masyarakat non muslim).

Daging konsumsi yang paling diminati oleh masyarakat adalah daging ayam (khususnya ayam broiler/ ayam potong). Ayam broiler memiliki banyak kelebihan yang tidak dimiliki oleh jenis ternak lain, misalnya pemeliharaan ayam broiler lebih cepat dan relative sangat singkat dibandingkan dengan pemeliharaan ternak lainnya seperti sapi, kambing, dan domba yang harus menghabiskan waktu berbulan-bulan lebih lama. Ayam broiler hanya membutuhkan waktu 32-35 hari dalam pemeliharaannya, kemudian bisa dipanen. Ayam broiler memiliki daging yang banyak dan karkas yang tinggi, serta memiliki ciri khas daging yang empuk. Masyarakat meminati ayam broiler tidak hanya karena kualitas dagingnya baik, namun juga karena harga jualnya yang ekonomis.

Ayam broiler terbagi menjadi dua macam usaha, yang pertama usaha on farm dan yang kedua merupakan usaha pasca panen, yang biasa dilakukan oleh RPA (Rumah Potong Ayam). Daging ayam broiler yang ketersediaannya tidak mampu untuk memenuhi kebutuhan konsumen, memaksa pengusaha RPA untuk mendatangkan daging ayam broiler dari daerah lain, hal ini mengharuskan pengusaha RPA untuk pintar dalam memanajemen waktu transportasi, agar ternak yang diperoleh sesuai dengan yang diharapkan.

Transportasi merupakan sesuatu yang tidak dapat dihindari untuk mendapatkan ternak yang diinginkan dari tempat lain, hal tersebut menjadikan kegiatan transportasi suatu kegiatan yang harus ada untuk mendapatkan daging yang dibutuhkan oleh konsumen. Transportasi memiliki peran yang sangat penting dalam kegiatan pemindahan ternak, pengeluaran dana menjadi bertambah, mulai dari dana pokok untuk transportasi itu sendiri sampai dana sampingan untuk menjaga hal yang tidak diinginkan pada saat dilakukan transportasi.

Suryadi, $d k k$ (2011) menyatakan transportasi merupakan kegiatan yang asing bagi ternak sehingga menjadi stresor utama dalam kegiatan pemindahan ternak dan akan memberi efek negatif

*) Staf Pengajar Jurusan Peternakan, Politeknik Negeri Jember

**) Staf Pengajar Jurusan Teknik, Politeknik Negeri Jember

***) Mahasiswa Jurusan Peternakan, Politeknik Negeri Jember 
pada ternak seperti ternak menjadi stress. Ternak dikatakan stress apabila terdapat tanda-tanda stress, seperti suhu tubuh yang tinggi, detak jantung meningkat, dan kandungan glukosa dalam darah meingkat. Stress yang dialami ternak dampaknya bermacam-macam seperti ternak cenderung diam, terjadi penurunan bobot badan, atau sampai terjadi kematian pada ternak. Ternak yang mengalami keadaan tersebut sangat merugikan pengusaha RPA, maka dari itu perlu dilakukan upaya-upaya pencegahan yang diharapkan akan bisa mengurangi efek negatif dari kegiatan tersebut.

Transportasi ternak membutuhkan manajemen yang baik agar kegiatan transportasi berjalan dengan baik dan tidak terjadi hal-hal yang buruk terhadap ternak yang bersangkutan, seperti terjadi penurunan bobot badan yang disebabkan karena ternak mengalami stres trasnportasi. Transportasi ternak harus dimanajemen dengan baik, salah satunya adalah dengan cara mengatur waktu dalam melakukan transportasi. Transportasi ternak dapat dilakukan dengan beberapa waktu, diantaranya adalah pada waktu pagi/ dini hari, siang hari, dan sore hari.

\section{METODOLOGI PENELITIAN \\ 2.1 Tempat dan Waktu}

Penelitian ini dilaksanakan di Politeknik Negeri Jember, Jl. Mastrip no 64 Jember Kecamatan Sumbersari Kabupaten Jember dan di rumah Bapak Syamsul Arifin, RT 01/01 Mangaran Kecamatan Mangaran Kabupaten Situbondo. Penelitian ini dilaksanakan selama 2 hari, mulai dari tanggal 8-9 November 2013.

\subsection{Alat dan Bahan}

Alat yang digunakan dalam pelaksanaan Tugas Akhir ini adalah mobil khusus pengangkut ayam broiler, thermometer, stopwatch, stetoskop, bolpoint dan kertas.

Bahan yang digunakan dalam pelaksanaan Tugas Akhir ini adalah ayam broiler finisher sebanyak 90 ekor.

\subsection{Metode Penelitian}

Metode yang digunakan dalam penelitian ini adalah Rancangan Acak Lengkap (RAL) dengan 3 perlakuan, setiap perlakuan terdiri dari 6 ulangan, setiap ulangan terdiri dari 5 ekor ayam broiler.

Perlakuan yang digunakan adalah:

a. P1= Pengangkutan ayam broiler pada dini hari (02.00 WIB)

b. $\mathrm{P} 2=$ Pengangkutan ayam broiler pada siang hari (12.00 WIB)

c. P3= Pengangkutan ayam broiler pada sore hari (16.00 WIB)

\subsection{Parameter Penelitian}

\subsubsection{Lama Perjalanan}

Lama Perjalanan = lama waktu perjalanan akhir - waktu awal perjalanan

\subsubsection{Penyusutan Bobot Badan}

Penyusutan $B B=B B$ awal $-B B$ akhir

\subsubsection{Denyut Jantung}

Denyut Jantung $(D J)=D J$ akhir $-D J$

awal

\subsubsection{Suhu Tubuh}

Suhu Tubuh $(S T)=$ ST akhir - ST awal

\subsubsection{Frekuensi Pernafasan} FP awal

$$
\text { Frekuensi Pernafasan }(F P)=F P \text { akhir - }
$$

\section{HASIL DAN PEMBAHASAN}

\subsection{Lama Perjalanan}

Perlakuan 1 (pengangkutan dini hari) mulai diangkut dari Jember pada pukul 02.00 WIB dan sampai di Situbondo pada pukul 03.32 WIB, maka lama perjalanan perlakuan 1 (pengangkutan dini hari) adalah 1 jam 32 menit. Perlakuan 2 (pengangkutan siang hari) mulai diangkut dari Jember pada pukul 12.00 WIB dan sampai di Situbondo pada pukul 14.11 WIB, maka lama perjalanan pada perlakuan 2 (pengangkutan siang hari) adalah 2 jam 11 menit. Perlakuan 3 (pengangkutan sore hari) mulai diangkut dari Jember pada pukul 16.00 WIB dan sampai di Situbondo pada pada pukul 17.57 WIB, maka lama perjalanan perlakuan 3 (pengangkutan sore hari) adalah 1 jam 57 menit.

Waktu pengangkutan sangat mempengaruhi lama perjalanan karena kondisi jalanan yang berbeda-beda, pada dini hari kondisi jalan akan sepi dan hampir tidak ada pengguna jalan sama sekali karena sedikit sekali masyarakat yang beraktivitas sehingga memungkinkan perjalanan bisa lebih lancar, terbukti pada perlakuan 1 yang diangkut pada dini hari memperoleh lama perjalanan tercepat yaitu 1 jam 32 menit.

Kondisi jalan pada siang hari sangat padat dengan aktivitas kendaraan mulai dari kendaran pekerja, siswa-siswi yang pulang sekolah, bahkan karyawan-karyawan kantor yang memadati jalan untuk mencari makan siang, hal tersebut sangat mengganggu kelancaran dalam melakukan pengangkutan ternak dan terbukti pengangkutan ternak yang dilakukan pada siang hari memperoleh waktu perjalanan terlama daripada pengangkutan ternak lainnya yaitu 2 jam 11 menit.

Kondisi jalan pada sore hari juga masih terbilang padat aktivitas karena banyak masyarakat yang akan pulang kerja, bahkan masih ada yang baru memulai aktivitas seperti pedagang pasar tradisional sore hari, hal tersebut memungkinkan masih bisa menghambat kelancaran pengangkutan ternak yang dilakukan pada sore hari, terbukti pada pengangkutan ternak yang dilakukan pada sore hari dalam penelitian ini memperolah lama perjalanan terlama kedua setelah pengangkutan ternak siang hari yaitu 1 jam 57 menit. 


\subsection{Penyusutan Bobot Badan}

Penyusutan bobot badan ayam karena perbedaan manajemen waktu pengangkutan terdapat pada Tabel 3.1.

Tabel 3.1 Penyusutan bobot badan (BB) ayam broiler (gr).

\begin{tabular}{ccccc}
\hline Perlakuan & $\begin{array}{c}\text { Rata- } \\
\text { rata BB } \\
\text { Awal }\end{array}$ & $\begin{array}{c}\text { Rata-rata } \\
\text { BB } \\
\text { setelah } \\
\text { transportasi }\end{array}$ & Penyusutan & $\begin{array}{c}\% \\
\text { (selisih) }\end{array}$ \\
\hline P1 & 1994.67 & 1933.00 & $61.67^{\mathrm{a}}$ & 3.09 \\
P3 & 2003.00 & 1915.67 & $87.33^{\mathrm{b}}$ & 4.36 \\
P2 & 1990.00 & 1817.67 & $172.33^{\mathrm{c}}$ & 8.66 \\
\hline Rataan & 1995.89 & 1888.78 & 107.11 & 5.37 \\
\hline
\end{tabular}

Keterangan: Angka yang diikuti huruf yang sama menunjukkan perbedaan tidak nyata.

Pada Tabel 3.1 tercermin bahwa rataan manajemen waktu pengangkutan terhadap penyusutan bobot badan ayam adalah 107, 11 gr/ekor dengan kisaran 61, 67 gr/ekor sampai dengan 172, 33 gr/ekor. Penyusutan bobot badan ayam terendah terdapat pada perlakuan 1 (pengangkutan dini hari) yaitu sebesar 61, 67 gr/ekor, sedangkan penyusutan bobot badan ayam tertinggi terdapat pada perlakuan 2 (pengangkutan siang hari) yaitu sebesar 172, 33 gr/ekor.

Penyusutan bobot badan ayam broiler tertinggi pada perlakuan 2 ini diduga transportasi siang hari menyebabkan cekaman paling kuat sehingga berdampak terhadap tingginya penyusutan bobot badan ayam. Medion (2008) menyatakan bahwa cekaman panas yang dihadapi oleh ayam pedaging akan mengakibatkan penurunan bobot badan bahkan mengalami kematian pada ayam dengan berat badan yang terlalu tinggi.

Ayam broiler yang mengalami penyusutan bobot badan merupakan konsekuensi dari stres yang dialami selama transportasi. Penyusutan bobot badan terjadi karena keluarnya pakan yang berada dalam saluran pencernaan berupa feses dan urine, sehingga dapat mengurangi bobot badan awal ayam broiler. Suryadi (2011) menyatakan bahwa penyusutan bobot badan ternak karena transportasi pada umumnya disebabkan hilangnya pakan dalam saluran pencernaan yang dikeluarkan dalam bentuk feses tanpa ada pakan yang dikonsumsi, serta dalam bentuk urine.

Ayam broiler selama transportasi tidak diberi pakan dan minum, sedangkan pakan yang tersimpan dalam saluran pencernaannya telah habis terserap dan dikeluarkan berupa feses dan urine, sehingga untuk melakukan metabolisme tubuh agar energi yang dibutuhkan tetap terpenuhi harus melakukan perombakan energi yang tersimpan dalam jaringan tubuhnya, hal ini akan menyebabkan terjadinya penyusutan bobot badan. Suryadi (2011) menyatakan bahwa transportasi ternak akan mengakibatkan proses metabolisme yang intensif, sehingga akan terjadi pengurasan cadangan makanan. Energi utama untuk kontraksi otot adalah glukosa dan asam lemak dalam darah, ketika otot kehabisan sumber energi utama maka ada cadangan energi (glikogen) berupa karbohidrat intramuskular (glikogen otot) dan karbohidrat ekstramuskular (glikogen hati).

\subsection{Frekuensi Denyut Jantung}

Peningkatan frekuensi denyut jantung ayam karena manajemen waktu pengangkutan terdapat pada Tabel 3.2.

Tabel 3.2 Frekuensi denyut jantung (DJ) ayam broiler (kali/menit).

\begin{tabular}{cccc}
\hline & $\begin{array}{c}\text { Rata- } \\
\text { rata } \\
\text { Perlakuan }\end{array}$ & Rata-rata DJ & \\
& Awal & $\begin{array}{c}\text { setelah } \\
\text { transportasi }\end{array}$ & DJ (selisih) \\
\hline P1 & 92.23 & 138.63 & $46.40^{\mathrm{a}}$ \\
P3 & 92.37 & 141.70 & $49.33^{\mathrm{ab}}$ \\
P2 & 117.20 & 173.17 & $55.97^{\mathrm{c}}$ \\
\hline Rataan & 100.60 & 151.17 & $50.57^{2}$ \\
\hline
\end{tabular}

Keterangan: Angka yang diikuti huruf yang sama menunjukkan perbedaan tidak nyata.

Pada Tabel 3.2 tercermin bahwa rataan manajemen waktu pengangkutan terhadap frekuensi denyut jantung adalah 50,57 kali/ekor dengan kisaran 46,40 kali/ekor sampai dengan 55,97 kali /ekor. Frekuensi denyut jantung terendah terdapat pada pengangkutan dini hari yaitu 46,40 kali/ekor, sedangkan frekuensi denyut jantung tertinggi terdapat pada pengangkutan siang hari yaitu 55,97 kali /ekor.

Ayam broiler yang diangkut pada perlakuan 2 ( pengangkutan siang hari) mengalami peningkatan frekuensi denyut jantung tertinggi, hal tersebut dikarenakan pada siang hari cekaman yang dihadapi ayam broiler sangat tinggi, diantaranya adalah tingginya cekaman panas, lamanya perjalanan, sampai tingginya tingkat kebisingan dan polusi udara yang diterima ayam broiler selama perjalanan. Frekuensi peningkatan denyut jantung merupakan konsekuensi dari cepatnya pernapasan untuk memenuhi ketersediaan oksigen agar proses oksidasi dan pengangkutan zat oleh darah tetap dapat tersalurkan kebagian tubuh yang membutuhkan.

Peningkatan frekuensi denyut jantung menunjukkan ciri stres yang dihadapi oleh ayam broiler selama trasnportasi, konsekuensi dari stres tersebut dapat mengakibatkan ayam broiler mengalami penyusutan bobot badan. Suryadi (2011) menyatakan bahwa perubahan fisiologis yang terjadi untuk merespon stresor pada ternak 
salah satunya adalah meningkatnya denyut jantung ternak. Medion (2008) menambahkan, stres yang dihadapi oleh ayam pedaging akan mengakibatkan penyusutan bobot badan bahkan mengalami kematian pada ayam yang memiliki bobot badan terlalu tinggi.

\subsection{Peningkatan Suhu Tubuh}

Peningkatan suhu tubuh ayam broiler karena manajemen waktu pengangkutan terdapat pada Tabel 3.3.

Tabel 3.3 Peningkatan suhu tubuh (ST) ayam broiler $\left({ }^{0} \mathrm{C}\right)$.

\begin{tabular}{clcc}
\hline & $\begin{array}{l}\text { Rata- } \\
\text { rata } \\
\text { Perlakuan }\end{array}$ & Rata-rata ST & Peningkatan \\
& Awal & $\begin{array}{c}\text { setelah } \\
\text { transportasi }\end{array}$ & ST (selisih) \\
\hline P1 & 39.81 & 40.57 & $0.76^{\mathrm{a}}$ \\
P3 & 39.95 & 40.88 & $0.94^{\mathrm{ab}}$ \\
P2 & 40.01 & 41.31 & $1.30^{\mathrm{b}}$ \\
\hline Rataan & 39.92 & 40.92 & 1.00
\end{tabular}

Keterangan: Angka yang diikuti huruf yang sama menunjukkan perbedaan tidak nyata.

Pada Tabel 3.3 tercermin bahwa perlakuan 1 rata-rata suhu tubuh awal ayam broiler $39.81^{\circ} \mathrm{C}$ dan setelah ditransportasi rata-rata suhu tubuh ayam broiler menjadi $40.57^{\circ} \mathrm{C}$, hal tersebut menunjukkan ayam broiler telah mengalami peningkatan suhu tubuh rata-rata sebanyak $0.76^{\circ} \mathrm{C}$. Ayam broiler pada perlakuan 2 memiliki suhu tubuh $40.01{ }^{\circ} \mathrm{C}$ dan setelah ditransportasi rata-rata suhu tubuh ayam broiler menjadi $41.31{ }^{\circ} \mathrm{C}$, hal tersebut menunjukkan ayam broiler telah mengalami peningkatan suhu tubuh sebanyak $1.30^{\circ} \mathrm{C}$. Ayam broiler pada perlakuan 3 memiliki rata-rata suhu tubuh awal $39.95^{\circ} \mathrm{C}$ dan setelah ditransportasi rata-rata suhu tubuh ayam broiler menjadi $40.88^{\circ} \mathrm{C}$, hal tersebut juga menunjukkan bahwa ayam broiler telah mengalami peningkatan suhu tubuh sebanyak $0.94^{\circ} \mathrm{C}$.

Ayam broiler yang mengalami peningkatan suhu tubuh tinggi berbanding lurus dengan penyusutan bobot badannya, hal ini dikarenakan banyaknya energi yang terpakai pada saat ayam mengalami cekaman panas. Kusnadi dan Rahim (2009) menyatakan bahwa ayam broiler yang menghadapi suhu tinggi akan terjadi penimbunan panas dalam tubuhnya, untuk mengurangi suhu yang tinggi maka ternak berusaha mengeluarkan panasnya, hal tersebut membutuhkan energi yang tinggi sehingga mampu menurunkan bobot badan ayam broiler.

\subsection{Frekuensi Pernapasan}

Peningkatan frekuensi pernapasan ayam broiler karena manajemen waktu pengangkutan terdapat pada Tabel 3.4.
Tabel 3.4 Peningkatan frekuensi pernapasan (FP) ayam broiler (kali/menit).

\begin{tabular}{|c|c|c|c|}
\hline Perlakuan & $\begin{array}{l}\text { Rata- } \\
\text { rata } \\
\text { FP } \\
\text { awal }\end{array}$ & $\begin{array}{c}\text { Rata-rata FP } \\
\text { setelah } \\
\text { transportasi }\end{array}$ & $\begin{array}{c}\text { Peningkatan } \\
\text { FP } \\
\text { (selisih) }\end{array}$ \\
\hline P1 & 31.47 & 71.74 & $40.27^{a}$ \\
\hline P3 & 35.00 & 114.10 & $79.10^{b}$ \\
\hline $\mathrm{P} 2$ & 35.57 & 140.14 & $104.57^{c}$ \\
\hline Rataan & 34.01 & 108.66 & 74.64 \\
\hline
\end{tabular}

Keterangan: Angka yang diikuti huruf yang sama menunjukkan perbedaan tidak nyata.

Pada Tabel 3.4 tercermin bahwa rataan manajemen waktu pengangkutan terhadap frekuensi pernapasan adalah 74,64 kali/menit/ekor dengan kisaran 40,27 kali/ekor sampai dengan 104,57 kali/menit/ekor. Frekuensi pernapasan terendah terdapat pada perlakuan 1 (pengangkutan dini hari) yaitu 40,27 kali/menit/ekor, sedangkan frekuensi denyut jantung tertinggi terdapat pada perlakuan 2 (pengangkutan siang hari) yaitu 104,57 $\mathrm{kali} / \mathrm{menit} / \mathrm{ekor}$.

Kondisi lingkungan pada siang hari terbukti lebih panas daripada kondisi lingkungan lainnya. Kondisi jalan pada siang hari sangat padat dengan ramainya aktivitas kendaraan, sehingga sangat mengganggu kelancaran dalam melakukan pengangkutan ternak dan terbukti pengangkutan ternak yang dilakukan pada siang hari memperoleh waktu perjalanan terlama daripada pengangkutan ternak lainnya yaitu 2 jam 11 menit, sehingga faktor-faktor tersebut dapat mengakibatkan tinginya cekaman terhadap ayam broiler yang diangkut pada siang hari. Wijayanti (2011) menyatakan, tingginya suhu lingkungan di daerah tropis pada siang hari mampu mencapai $34^{\circ} \mathrm{C}$ dan dapat mengakibatkan terjadinya penimbunan panas dalam tubuh, sehingga ternak mengalami cekaman panas. Ayam broiler termasuk hewan homeothermis dengan suhu nyaman $24^{\circ} \mathrm{C}$, akan berusaha mempertahankan suhu tubuhnya dalam keadaan relatif konstan antara lain melalui peningkatan frekuensi pernafasan.

\section{KESIMPULAN DAN SARAN 4.1 Kesimpulan}

Hasil penelitian manajemen waktu pengangkutan dalam meminimalisir penyusutan bobot badan ayam broiler adalah sebagai berikut:

1. Penyusutan bobot badan tertinggi terdapat pada perlakuan 2 (pengangkutan siang hari) yaitu 172,33 gr/ekor dan penyusutan bobot badan terendah terdapat pada perlakuan 1 yaitu 61,67 gr/ekor. 
2. Frekuensi denyut jantung tertinggi terdapat pada perlakuan 2 (perlakuan siang hari) yaitu 55,97/menit setiap ekor dan frekuensi denyut jantung terendah terdapat pada perlakuan 1 (pengangkutan dini hari) yaitu 46,4/menit setiap ekor.

3. Peningkatan suhu tubuh tertinggi terdapat pada perlakuan 2 (perlakuan siang hari) yaitu 1,3/menit setiap ekor dan peningkatan suhu terndah terdapat pada perlakuan 1 (pengangkutan dini hari) yaitu $0,76 /$ menit setiap ekor.

4. Frekuensi pernapasan tertinggi terdapat pada perlakuan 2 (perlakuan siang hari) yaitu 104,57/menit setiap ekor dan frekuensi pernapasan terendah terdapat pada perlakuan 1 (pengangkutan dini hari) yaitu 40,27/menit setiap ekor.

4.2 Saran

1. Pengangkutan ayam broiler sebaiknya dilakukan pada dini hari, karena pada dini hari ayam akan mengalami penyusutan bobot badan lebih rendah.

2. Pengangkutan ayam broiler sebaiknya tidak dilakukan pada siang hari, karena ayam akan mengalami penyusutan bobot badan yang tinggi.

\section{UCAPAN TERIMA KASIH}

Kami ucapkan terima kasih atas selesainya penelitian dan penulisan jurnal ini kepada :

1. Ir. Nanang Dwi Wahyono, MM selaku Direktur Politeknik Negeri Jember.

2. Dr. Ir. Bagus P. Yudhia K., MP selaku Pembantu Direktur Bidang Akademik Politeknik Negeri Jember.

3. Ir. Michael Joko Wibowo, MT selaku Ketua Pusat Penelitian dan Pengabdian Mayarakat Politeknik Negeri Jember.

4. Ketua Jurusan Peternakan.

5. Ketua Jurusan Teknik.

6. Kepala Laboratorium Jurusan Peternakan.

7. Kepala Laboratorium Mesin Otomotif.

\section{DAFTAR PUSTAKA}

Berutu, K.M. 2007. Dampak Lama Transportasi Terhadap Penyusutan Bobot Badan, pH Daging Pasca Potong Dan Analisis Biaya Transportasi Sapi Potong Peranakan Ongole (PO) Dan Shorthorn. Fakultas Pertanian. Medan: Universitas Sumatera Utara.

Cinnata. 2008. Konversi Otot Menjadi Daging. http://cinnatalemieneabustam.blogspot.com/20/08/04/ konversi-otot-menjadi-daging.html
Hanafiah, K.A. 2012. Rancangan Percobaan Teori dan Aplikasi. RajaGrafindo Persada. Jakarta.

Ilham, N. dan Y. Yusdja. 2004. Sistem Transportasi Perdagangan Ternak Sapi dan Implikasi Kebijakan di Indonesia. Pusat Penelitian dan Pengembangan Sosial Ekonomi Pertanian. Bogor.

Karaman, M. 2009. Effect of Transport Time on Body Performance of Broilers During Transit to Slaughter House. Jurnal of Animal and Veterinary Advances. Vol 8. Hal: 1555-1556.

Kusanadi, E. dan F. Rahim. 2009. Performa Dan Kandungan Hormon Triiodotironin Plasma Ayam Broiler Akibat Pengaruh Cekaman Panas Di Daerah Tropis. Media Peternakan. Vol. 32 No. 3. Hal: 155-162.

Medion. 2008. Optimalkan Produksi Saat Heat Stress. Info Medion. Edisi Juli 2008.http://info.medion.co.id/index.php/ar tikel/layer/tatalaksana/produksi-saat-heat$\underline{\text { stress }}$

Nangoy, F.J. 2012. Kajian Penyusutan Berat Badan dan Peningkatan Suhu Tubuh Ayam Broiler Terimplemintasi Kurkuma (Curcuma Longa), Gula Aren (Arenga Pinata) Akibat Lama Transportasi. IJS. Volume 2 Nomor 3. Universitas Sam Ratulangi.

Nurrasyidah D, Yulianti A dan Mushawwir A. 2012. Status Hematologis Domba Ekor Gemuk Jantan Yang Mengalami Transportasi. Bandung: Unpat Press. Laporan Penelitian.

Rahman, A.A. 2012. Presentase Karkas Dan Income Over Feed And Chick Cost Pada Broiler Yang Mendapat Ransum Mengandung Berbagai Level Tepung Daun Katuk. Fakultas Peternakan. Makassar: Universitas Hasanuddin.

Rasyaf, M. 2008. Panduan Beternak Ayam Pedaging. Jakarta: Penebar Swadaya.

2011. Pengelolaan Usaha Peternakan Ayam Pedaging. Jakarta: PT Gramedia Pustaka Utama.

Rinastiti A.L. 2013. Heat Stress - Cekaman Panas Pada Ayam.

*) Staf Pengajar Jurusan Peternakan, Politeknik Negeri Jember

**) Staf Pengajar Jurusan Teknik, Politeknik Negeri Jember

***) Mahasiswa Jurusan Peternakan, Politeknik Negeri Jember 
Jurnal Ilmiah INOVASI, Vol. 15 No.1, Hal. 14-19, Januari - April 2015, ISSN 1411-5549

http://lintangrinastiti.blogspot.com/ 2013/05/ heatstress-cekaman-panas-pada-ayam.html

Santosa U, Tanuwira U, Yulianti A, Suryadi U. 2012. Pemanfaatan Kromium Organik Limbah Penyamakan Kulit untuk Mengurangi Stres Transportasi dan Memperpendek Periode Pemulihan pada Sapi Potong. JITV. vol 17. No 2. 132-141.

Sudja B dan Laila S. 2012. Biologi 3A Sains Dalam Kehidupan. Jakarta: Yudhistira.

Suryadi U, Santosa U dan Tanuwira U. 2011. Strategi Eliminasi Stres Transportasi Pada Sapi Potong Menggunakan
Kromium Organik. Bandung: Unpat Press. Laporan Penelitian.

Wijaya, A.M. 2010. Faktor-Faktor Kemacetan Di Jakarta Dan Pemecahan Masalahnya. http://www.infodokterku.com/index.php.

Wijayanti R P, Busono W, Indrawati R. 2011. Pengaruh Suhu Kandang Yang Berdeda Terhadap Performans Ayam Pedaging Periode Starter. Laporan Penelitian. Malang: University of Brawijaya.

Zaif. 2009. Metabolisme Hewan. http://zaifbio.wordpress.com/2009/03/29/ metabolisme-hewan.html 